\title{
Pools and rapids as spawning and nursery areas for fish in a river stretch without floodplains
}

\author{
Sunshine de Ávila-Simas ${ }^{1}$, David Augusto Reynalte-Tataje ${ }^{2}$ and Evoy Zaniboni-Filho ${ }^{1,3}$
}

This study aimed to evaluate the importance of two environments situated in the main channel of the Peixe River (a tributary of the upper Uruguay River) on fish reproduction and initial growth. Ichthyoplankton, macrozooplankton, and zoobenthos collections were taken on a monthly basis from October 2011 to March 2012, sampling a rapids and a pool environment. The instrument used for the capture of the ichthyoplankton in both environments was a light trap. In total, 795 eggs and 274 larvae were captured. The species that presented higher abundance and occurrence frequency out of the total captured in both environments were Leporinus obtusidens, Bryconamericus iheringii, and Bryconamericus stramineus. The evaluation of the feeding activity reveals a major repletion degree of the larvae in more advanced stages in the pool. The pool environment presented a higher abundance of larvae in more advanced development stages. We conclude that the channel of the Peixe River is important for the reproduction and initial growth of fish and that each river environment seems to fulfill a different role in the life cycle of the ichthyoplankton community.

Este trabalho avaliou a importância de dois ambientes situados no canal principal do rio do Peixe (afluente do alto rio Uruguai) na reprodução e crescimento inicial dos peixes. As coletas de ictioplâncton, macrozooplâncton e zoobentos foram realizadas mensalmente no período de outubro de 2011 a março de 2012, amostrando um ambiente de corredeira e um ambiente de poço. $\mathrm{O}$ instrumento utilizado para a captura do ictioplâncton nos dois ambientes foi a armadilha luminosa. No total, foram capturados 795 ovos e 274 larvas. As espécies que apresentaram maior abundância e frequência de ocorrência do total capturado nos dois ambientes foram Leporinus obtusidens, Bryconamericus iheringii e Bryconamericus stramineus. A avaliação da atividade alimentar revela um maior grau de repleção das larvas em estágios mais avançados no ambiente de poço. O ambiente de poço apresentou uma maior abundância de larvas nos estágios mais avançados de desenvolvimento. Conclui-se que o canal do rio do Peixe é importante para a reprodução e crescimento inicial de peixes e que cada ambiente do rio parece cumprir um papel diferente no ciclo de vida da comunidade ictioplanctônica.

Key words: Fish breeding, Larvae feeding, Migratory, Nursery environments, Upper Uruguay River.

\section{Introduction}

It is well known that one of the factors responsible for ensuring the success of fish recruitment is the rapid transition of a species through the initial stages of the growth cycle, for which the mortality rate is extremely high (Houde, 2002). During this period, fish juveniles tend to occupy temporary or permanent environments in which the biological, physical and chemical conditions are favorable for their growth. The abundance of available food, low water stream speed and low predation pressure are among the main characteristics of such sites (Houde, 2002; Werner, 2002).
In developing fish stock management and conservation activities, studies involving the first stages of the life cycle of fish are of great importance because the detection of certain stages of their life cycle serves as an indicator of environmental conditions (Copp et al., 1991; Penczak, 1994), as well as helps locating the habitats used by different species in the environment (Silva et al., 2012).

In this sense, several authors have recognized that knowledge regarding spawning sites and natural nurseries is valuable because it serves as a tool for the protection of fish populations and the management of fishery resources (Nakatani et al., 2001; Silva et al., 2012). Baumgartner et al.

${ }^{1}$ Universidade Federal de Santa Catarina, Centro de Ciências Agrárias, Departamento de Aquicultura, Laboratório de Biologia e Cultivo de Peixes de Água Doce. Rodovia SC-406, №.3532, 88066-000 Florianópolis, SC, Brazil. sunshine_avila@hotmail.com

${ }^{2}$ Universidade Federal Fronteira Sul (UFFS), Campus Cerro Largo. Rua Major A. Cardoso 590, Centro, 97900-000 Cerro Largo, RS, Brazil. reynalted@hotmail.com

${ }^{3}$ Universidade Federal de Santa Catarina, Centro de Ciências Agrárias, Departamento de Aquicultura, Programa de Pós-Graduação em Aquicultura. Rodovia Ademar Gonzaga, №. 1346, 88034-001 Florianópolis, SC, Brazil. evoy@lapad.ufsc.br 
(2004) also emphasize that the preservation of these sites is of great importance to ensure good recruitment of any species.

It is widely accepted that the environments of seasonally inundated floodplain rivers, such as pools and marginal lagoons, are important habitats for the spawning and development of several fish species (Welcomme, 1979, 1985; Junk et al., 1989). This model has been used for native fish in floodplain rivers in several locations (Castro et al., 2002; King, 2004). Several studies (Humphries et al., 1999; Galat \& Zweimüller, 2001; King et al., 2003) have questioned the generalization of this model because the main river channel, in its diverse structural mosaic, can also offer favorable conditions for the development of larvae through the lateral habitats located along the banks, which are characterized by a low flow speed and the subsidence of thin particles. In addition, Humphries et al. (2002) mention the possibility of several species being able to spawn and recruit in the main channel of the river during the low water period, when the access to floodplain environments is unavailable.

The upper Uruguay River presents hydrological and morphometric characteristics that differentiate it from other rivers belonging to the La Plata basin. In this region, the Uruguay River is located in a valley without a floodplain and with the absence of lagoons. These features indicate that the fish community present here represents different reproductive strategies from those found in the rest of the La Plata basin (Reynalte-Tataje et al., 2008a). In the upper Uruguay River, the tributaries are generally not extensive and contain numerous waterfalls, which would interfere with the migration of rheophilic fish species between the main river and its tributaries (Zaniboni-Filho \& Schulz, 2003).

Despite the importance of this information, little is known about the feeding sites and the development of fish larvae in the upper Uruguay River. Studies have confirmed the existence of spawning in the region (Reynalte-Tataje et al., 2008a; Hermes-Silva et al., 2009), and more recently, Silva et al. (2012) observed local growth and spawning of fish in a tributary located in this region.

Several models claim that pool environments located in the upper Uruguay River provide favorable conditions for the development of planktonic and benthic organisms, allowing for the growth of fish larvae, while rapids environments may be used as spawning sites and for larval drift (Reynalte-Tataje et al., 2008b; Silva et al., 2012). This study aimed to test this hypothesis and to investigate if the spawning and nursery areas found by Silva et al. (2012) in one tributary are also found in other tributaries of the upper Uruguay River. Accordingly, we have compared the distribution and abundance of fish eggs and larvae in initial stages in two different environments of the Peixe River (upper Uruguay River). The hypothesis may be evaluated through analysis of the abundance of the different larvae stages in the two studied environments (rapids and pools). Furthermore, analysis of the food contents of the digestive tracts of larvae and assessment of biotic variables (zooplankton and zoobenthos) can also help in understanding the importance of each environment in the development of juvenile fish forms.

\section{Material and Methods}

\section{Study area}

The Peixe River is located on the right bank of the upper Uruguay River (Santa Catarina State, Brazil) within the reservoirs of the Itá and Machadinho dams. This river flows in an area influenced by the reservoir of the Itá dam, in a lentic-lotic transitional section of the Uruguay River (Fig. 1). The river is $290 \mathrm{~km}$ long, and its draining area corresponds to $5,221 \mathrm{~km}^{2}$, with an average flow of $243 \mathrm{~m}^{3} / \mathrm{s}$. Because of these characteristics, the Peixe River is considered a tributary of great importance in the breeding shift of the Itá reservoir fish populations (Reynalte-Tataje et al., 2008a).

Samples were obtained from two environments in the Peixe River: rapids and pools. The rapids environment from which the samples were taken $\left(28^{\circ} 34^{\prime} 49^{\prime \prime} \mathrm{S} 52^{\circ} 13^{\prime} 08^{\prime \prime} \mathrm{W}\right)$ presents lotic characteristics and a length of approximately 500 meters long and 65 meters wide. In the rapids, traps were installed in the banks at an average depth of 1.5 meters. The pool (28 $\left.34^{\prime} 23^{\prime \prime S} 52^{\circ} 12^{\prime} 54^{\prime \prime} \mathrm{W}\right)$ presents lentic characteristics with a length of approximately 300 meters by 90 meters wide. The greatest depth observed in this environment was 24 meters; therefore, the light traps used for the capture of ichthyoplankton were installed in the river banks at places with an average depth of 2.5 meters. The distance between the two collection points is approximately 1,300 meters.

Both environments exhibit a rocky bottom formed by basaltic rocks and the absence of macrophytes on the surface. The flora present in the river is affected by human occupation, and this region also suffers from other anthropogenic effects, such as the release of waste into the river channel from animal husbandry effluents.

\section{Sampling}

The ichthyoplankton collections were performed monthly between October 2011 and March 2012, each with a duration of three days. Light traps were used to capture the ichthyoplankton.

The model of light traps used in this study (Fig. 2) was adapted from Reynalte-Tataje et al. (2012a). These traps were made with a conical-cylindrical design, a PVC cylindrical pipe and a $500 \mu \mathrm{m}$ conical net carrying a PVC sample bucket on its distal end. A net ( $8 \mathrm{~mm}$ mesh) was placed at the proximal end to prevent the entry of larger fish, vegetation and other unwanted materials. The lighting of the traps was provided by an acrylic structure containing a battery $(9 \mathrm{~V})$ and a LED lamp $(1 \mathrm{~W})$. This structure was set to remain illuminated inside the PVC cylindrical pipe in the proximal part of the trap. Green light was used in the trap, which is considered by Reynalte-Tataje et al. (2012a) to represent the best larvae capture rates. The light traps were installed at nightfall (7 p.m.) and removed before sunrise (5 a.m.). The position of the light traps in the environment was randomly chosen, ensuring that each of the environments contained three light traps for each of the monthly threenight samples. 


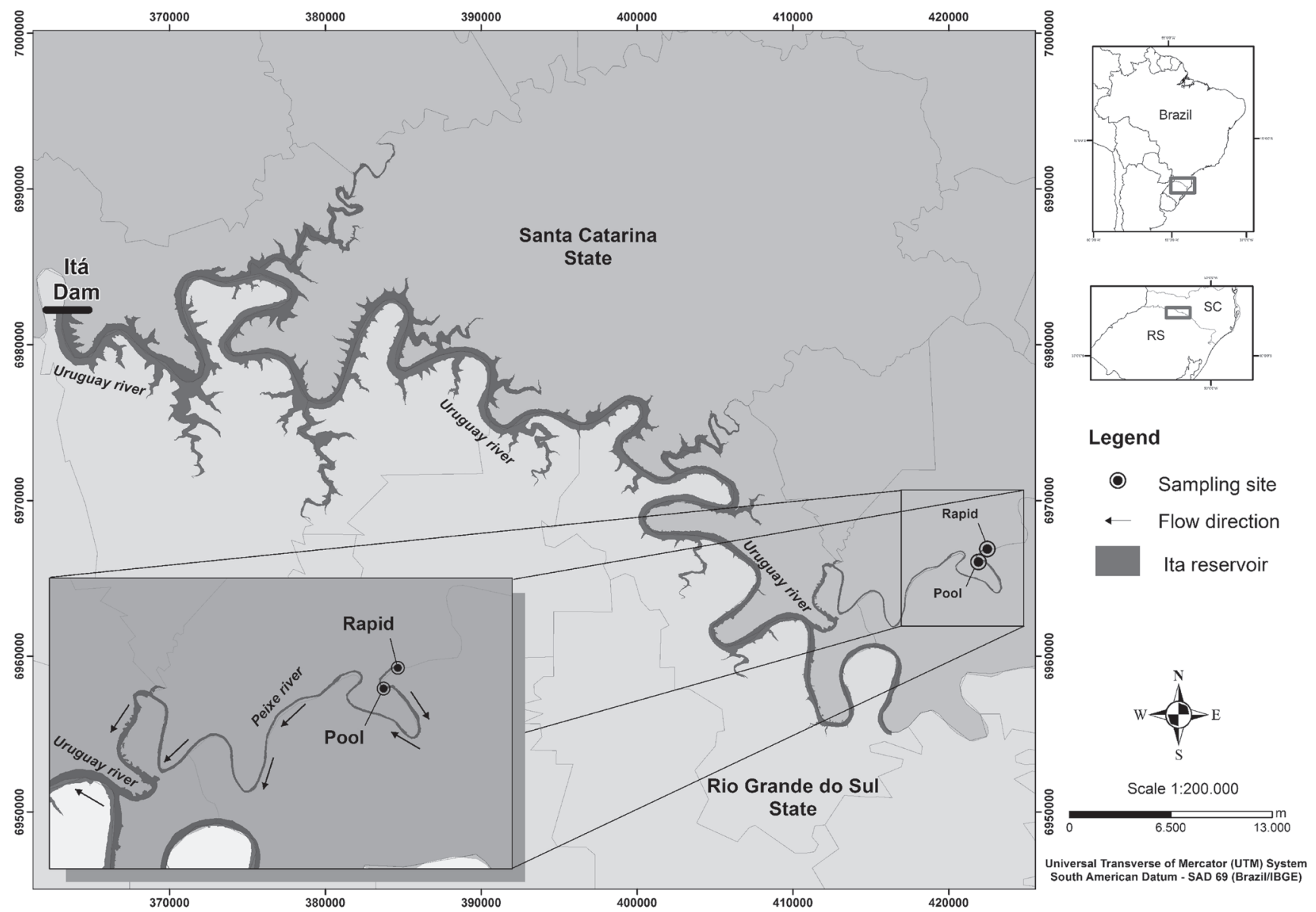

Fig. 1. Location of the sampling sites in the Peixe River.

All material collected was individually packaged in 500 $\mathrm{mL}$ polyethylene vessels and then fixed in $4 \%$ formalin for later analysis in the laboratory.

Along with the ichthyoplankton collections, samples of macrozooplankton and zoobenthos were collected in both environments. For the macrozooplankton analysis, three samples of $100 \mathrm{~L}$ of water were collected in each environment. The water was subsequently filtered through a $70 \mu \mathrm{m}$ net and fixed in $500 \mathrm{~mL}$ polyethylene vessels of $4 \%$ formalin. However, benthic community samples were performed with the help of a Van Veen $\left(377 \mathrm{~cm}^{2}\right)$ dredge. Three samples were obtained in each of the environments, with each sample corresponding to a release from the dredge at the same point where the ichthyoplankton collections were held. The material captured by the dredge was washed with a $500 \mu \mathrm{m}$ mesh strainer to remove the sediment excess. The content retained in the strainer was packed in $5 \mathrm{~L}$ gallon containers and fixed in $8 \%$ formalin.

The abiotic factors, such as temperature, oxygen, $\mathrm{pH}$, electrical conductivity, transparency and water speed, were also measured and recorded. Temperature and dissolved oxygen measurements of the water were taken with a YSI-55 oximeter. The $\mathrm{pH}$ and electric conductivity values were obtained with a YSI-63 multiparameter. The water transparency was measured with a Secchi disc. Precipitation and water flow data were provided by Consórcio de Itá.

\section{Laboratory analysis}

At the laboratory, the samples were screened, and the ichthyoplankton was separated from the remaining material. For the separation and counting of eggs and larvae, the samples were put in a Bogorov chamber under a stereoscopic microscope (10x magnification). Larvae were identified to the lowest possible taxonomic level, in accordance with Nakatani et al. (2001) and Reynalte-Tataje \& Zaniboni-Filho (2008). Additionally, larvae were separated according to the degree of development of the caudal fin into the following stages: larval yolk (LY), preflexion (PF), flexion (F) and postflexion (PosF), according to Ahlstrom \& Moser (1976) and as modified by Nakatani et al. (2001). Due to the difficulty in separating some larvae of the family Loricariidae into the larval stages described above, only larvae of up to $40 \mathrm{~mm}$ in total length were considered for this analysis.

Macrozooplankton samples with formalin were strained through a $70 \mu \mathrm{m}$ mesh, concentrated into $50 \mathrm{~mL}$ bottles and conserved in $70 \%$ alcohol. The samples placed in a Bogorov 


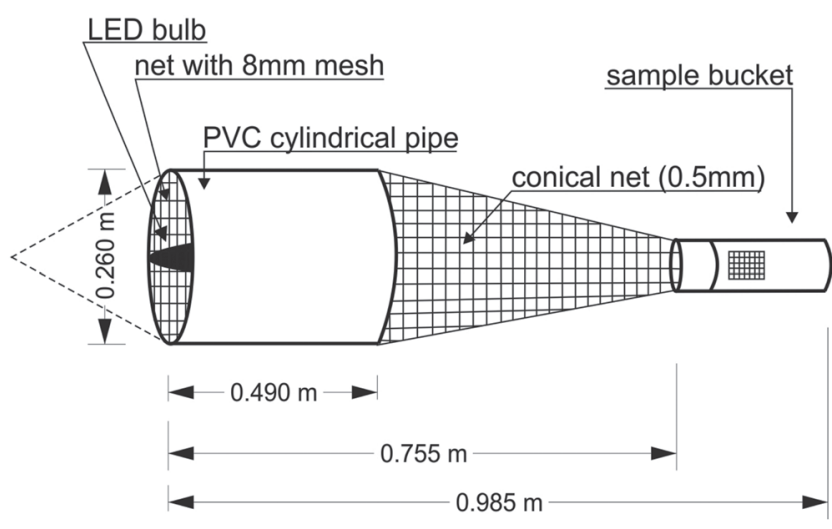

Fig. 2. Light trap used to capture the ichthyoplankton.

counting chamber and analyzed under a binocular dissecting microscope for screening and organism counting. For the quantitative analysis, only two groups were considered: copepods and cladocerans, since these were the only groups found in the analyzed material.

The zoobenthic community samples were washed under a low pressure water jet in a $500 \mu \mathrm{m}$ mesh strainer. The material retained by the strainer was put into $500 \mathrm{~mL}$ polyethylene vessels and stained with alcohol-based Rose-Bengal solution $(1 \mathrm{~g} / 1000 \mathrm{~mL})$. The screening of the material was performed with PVC trays under a light source. The individuals found were kept in $70 \%$ alcohol and quantified.

\section{Stomach analysis}

The stomachs were analyzed with the purpose of investigating the feeding activity of the different larval stages (PF, F, and PosF) in both studied environments. The taxa most frequently found throughout the collection period were selected, and the larvae used were in the later development stages. For the stomach removal, the larvae were placed in Petri dishes, and a longitudinal cut was made in the abdominal region with the help of a scalpel. Subsequently, the degree of stomach fullness was determined for each analyzed stomach. These values varied between 1 and 4 , where $1=$ empty (foodfree stomach), 2 = partially empty (up to $25 \%$ full), 3 = partially full ( $26 \%$ to $75 \%$ full), and $4=$ full (over $75 \%$ full). Finally, the stomachs were opened, and their contents were identified under an optical microscope. The feeding activity was analyzed based on the average repletion degree $(\mathrm{Gr})$ according to the equation $\mathrm{Gr}=(1 \mathrm{n} 1+2 \mathrm{n} 2+3 \mathrm{n} 3+4 \mathrm{n} 4) /(\mathrm{n} 1+\mathrm{n} 2+\mathrm{n} 3+\mathrm{n} 4)$, where $1 . . .4=$ number of stomachs with the distinct repletion degrees $(1,2,3$, and 4) (adapted from Marçal-Simabuku \& Peret, 2002).

\section{Data analysis}

Space-time variation (sampling sites and months) of fish eggs and larvae abundance was analyzed by a factorial ANOVA. When the results were significant $(\mathrm{p}<0.05)$, the Tukey's test was applied with the purpose of detecting such differences.
To determine the most important species, calculations were performed to estimate the average densities during the analyzed period and the occurrence frequency (values calculated only for fish identified to genus and species).

For the stomach content analysis, only the species presenting over $6 \%$ occurrence frequency were selected, with the objective of minimizing the influence of the least representative species.

A Canonical Correlation Analysis (CCA) was performed to analyze the relation between the developmental stages of the ichthyoplankton and the set of environmental variables (Ter Braak, 1995). To reduce the data dimension, the abiotic factors were first transformed $\left(\log _{10} \mathrm{x}+1\right)$, except for $\mathrm{pH}$ (Peters, 1986). All of the ordinations were performed using PCORD 5.0 software with a 0.05 significance limit. The ANOVA was performed with the STATISTICA v. 7.0 package.

\section{Results}

\section{Taxonomic composition}

Considering both studied environments, a total of 274 larvae representing four orders, 12 families and 18 species was captured. The Characiformes order was the most representative one, with $90.91 \%$ of the total number of captured larvae, followed by Siluriformes (7.64\%) and Atheriniformes (1.09\%). The Perciformes order presented less than $1.0 \%$ of the total captured larvae. Of the 12 families encountered, those with a greater number of species were Characidae, with 10 representatives, followed by Anostomidae, with three species (Table 1).

Six species were present in both rapids and pool environments. Among them, the most frequently occurring ones were Leporinus obtusidens (14.81\%), Bryconamericus iheringii (9.26\%), and Bryconamericus stramineus (8.33\%), which also presented the largest abundances in both environment. Some of the species caught are presented in Fig. 3.

\section{Stomach content}

The stomach contents of 216 larvae were examined, of which 176 were empty, 25 were partially empty, eight were partially full, and seven were full (Fig. 4). Of the total analyzed stomachs, only 12 corresponded to larvae captured in the rapids environment, nine of which presented an empty stomach, and three of which were partially empty. Most larvae were captured in the pool environment because only in this environment was it possible to register individuals with a partially full and full repletion degree. Therefore, it was possible to observe that in both environments, the number of empty stomachs was high (Fig. 4).

\section{Spatio-temporal variation of environmental variables Abiotic factors}

The environmental variables presented similarities between the collection points, except for water velocity, which was significantly higher in the rapids than in the pool environment (Table 2). 


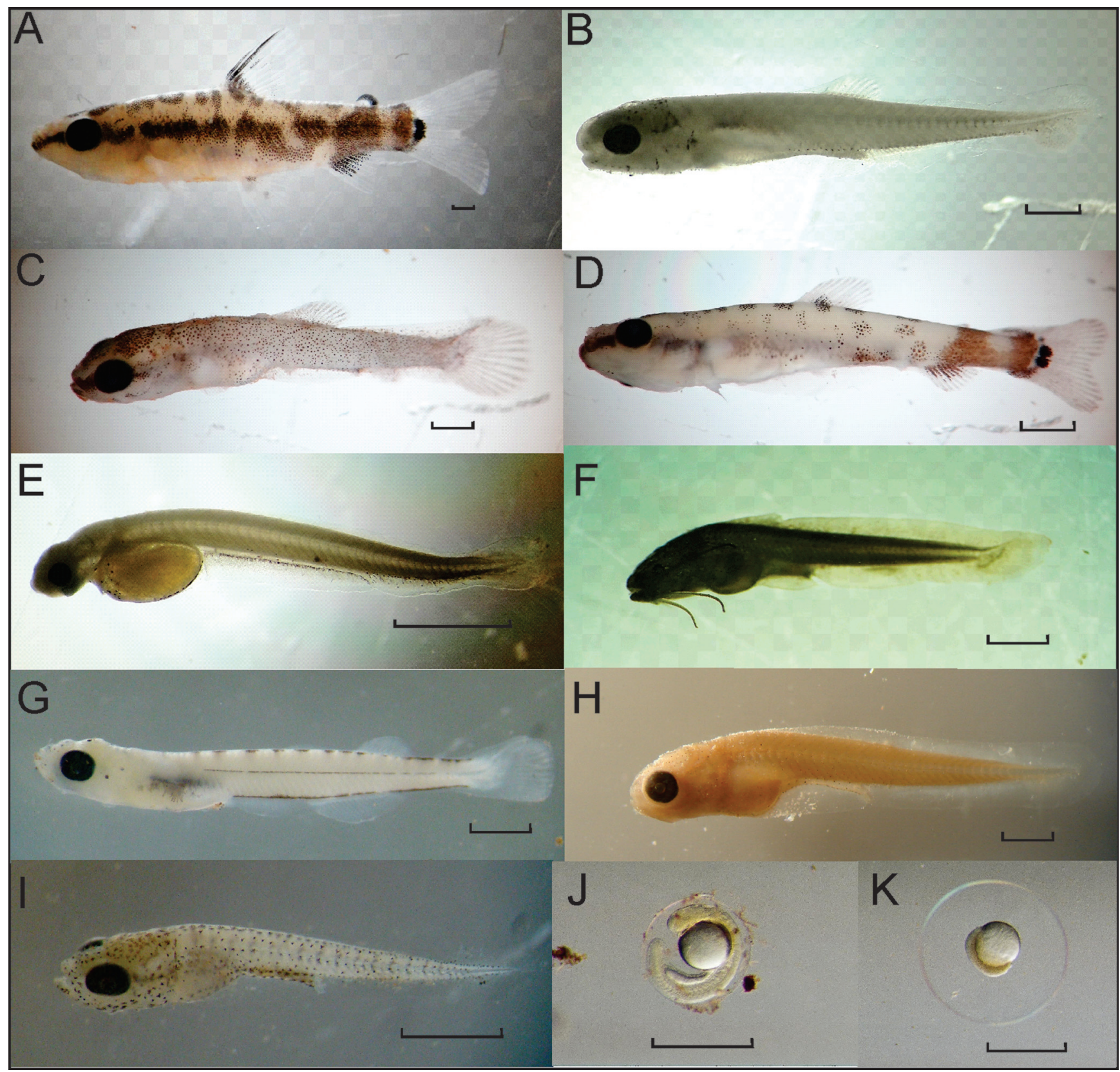

Fig. 3. Some species of fish larvae found in the upper Uruguay River: (A) Leporinus amae, (B) Bryconamericus stramineus, (C) Hoplias spp., (D) Leporinus obtusidens, (E) Schizodon aff. nasutus, (F) Rhamdia quelen, (G) Odontesthes aff. perugiae, (H) Serrasalmus maculatus, (I) Astyanax jacuhiensis, (J) Steindachnerina spp. egg and (K) Apareiodon affinis egg (Scale = $1 \mathrm{~mm})$.

During the collection months, the average flow was found in October, coinciding with the month that registered the highest average monthly precipitation (Fig. 5).

\section{Biotic factors}

Through ANOVA, we could observe that there was a difference in the abundance of the macrozooplankton in relation to the collection month $(F(5,24)=3.1427 ; p<0.05$, Fig. 6 ), notable only when comparing the months of November and January. There was no significant difference in the macrozooplankton abundance between the rapids and the pool environments.

The benthic community presented a difference in the spatio-temporal distribution $(F(5,24)=4.5441 ; p<0.05$, Fig. 7$)$, with the highest capture rate found in the rapids environment in December and the lowest rate found in the pool environment in February.

\section{Spatio-temporal variation in ichthyoplankton abundance}

For six months, 795 eggs and 274 larvae were collected. The number of eggs corresponded to $74.37 \%$ of all of the ichthyoplankton captured, whereas the larvae reached a total 


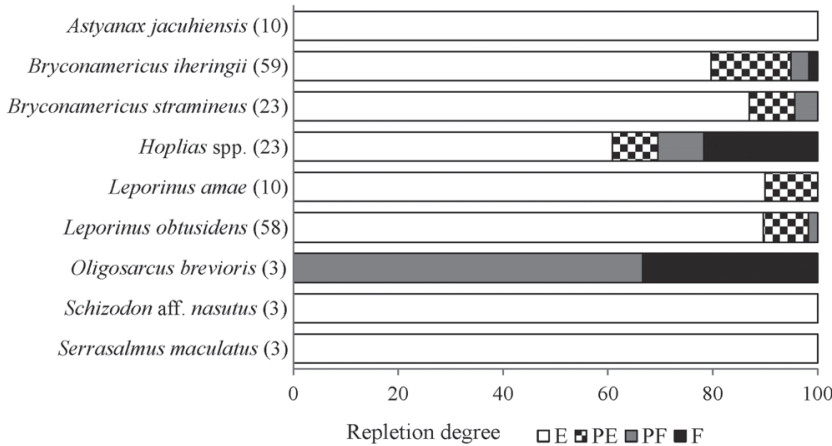

Fig. 4. Average repletion degree (\%) of the captured larvae digestive tract from both environments of the Peixe River, from October 2011 to March 2012. Number of larvae examined is shown in brackets. Repletion degree: E - empty; PE - partially empty; PF - partially full; F - full.

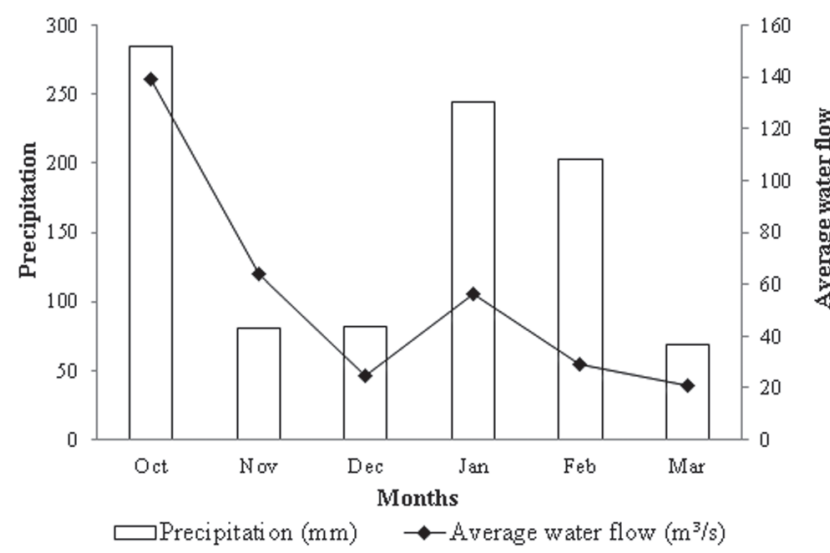

Fig. 5. Average flow and precipitation ratings registered in the Peixe River, from October 2011 to March 2012. Source: Consórcio de Itá.

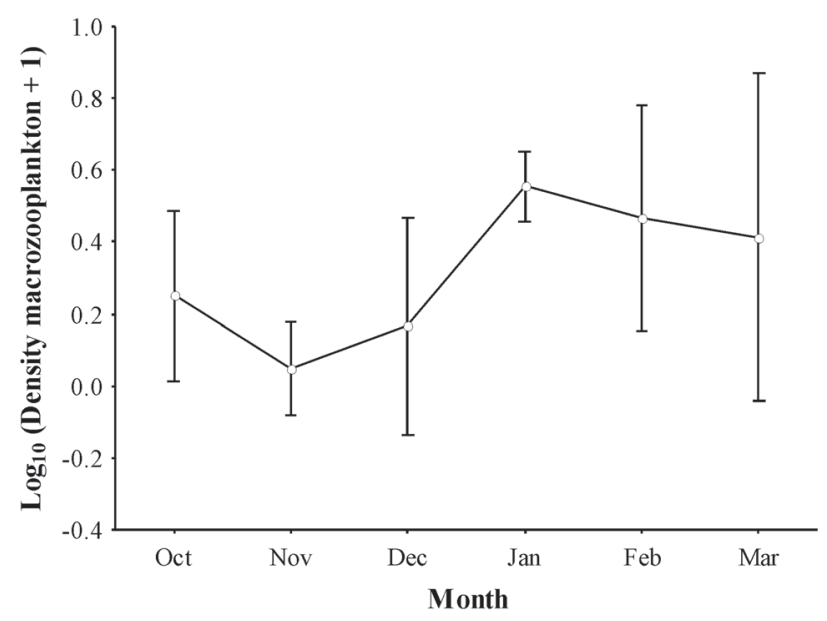

Fig. 6. Average density \pm standard deviation of the macrozooplankton organisms captured in both environments (rapids and pool) of the Peixe River, between October 2011 and March 2012.

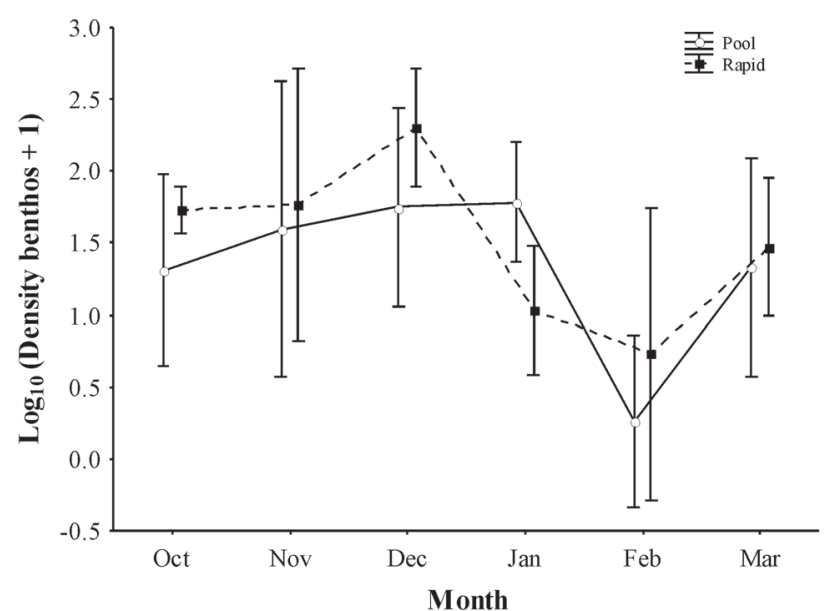

Fig. 7. Average density \pm standard deviation of the spatiotemporal distribution of benthic organisms captured in the rapids and pool environments in the Peixe River, between the months of October 2011 and March 2012.

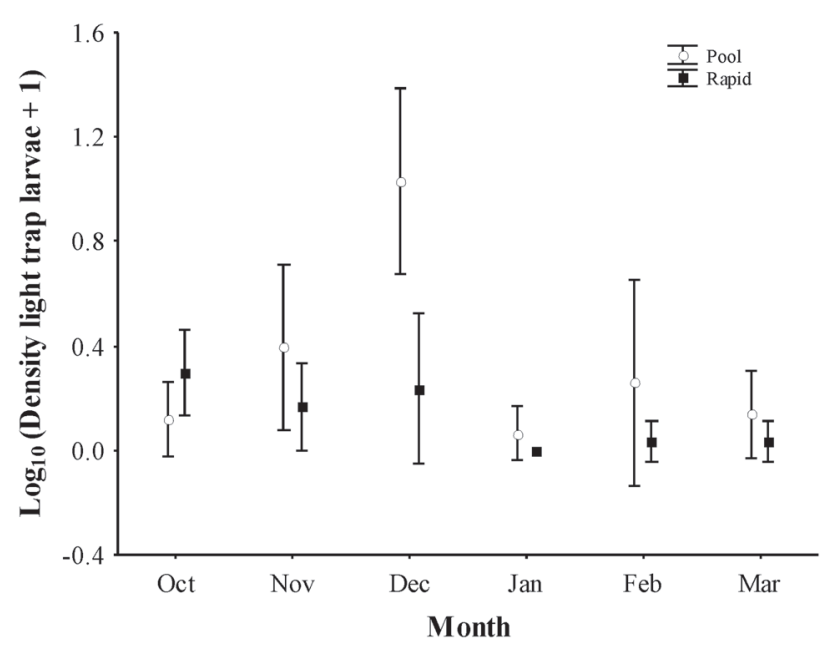

Fig. 8. Average density \pm standard error of the larvae captured in the Peixe River with light traps in different environments and months from October 2011 to March 2012.

of $25.63 \%$. For the total amount of eggs captured, no interaction was found between the environmental and temporal factors $(\mathrm{F}(5,96)=1.9107, \mathrm{p}>0.05)$. Conversely regarding the total amount of larvae captured, an interaction was found between the environmental and temporal factors $(F(5,96)=5.6141, p<0.05)$, with the largest number of captured larvae occurring in the pool environment in December. During the remaining months, the larvae abundance values in both environments were similar (Fig. 8).

Considering all of the captured larvae stages, only the larvae density in the larval yolk phase did not present an interaction among the environmental and temporal factors. Regarding the larvae captured in the preflexion stage, the largest abundances in the pool environment were observed in December and November. The lowest values, however, were 
Table 1. Occurrence frequency $(\mathrm{FO} \%)$ and average density of fish larvae in the different sampling sites captured with light traps in the Peixe River between October 2011 and March 2012 (R - rapids environment; P - pool environment; total - total larvae captured; LY - larval yolk; PF - preflexion; F - flexion; PosF - postflexion). *values correspondent to individuals measuring up to $40 \mathrm{~mm}$ in length.

\begin{tabular}{|c|c|c|c|c|c|c|c|c|c|c|}
\hline \multirow{2}{*}{ Taxa } & \multirow{2}{*}{$\mathrm{FO} \%$} & \multirow{2}{*}{ Total } & \multicolumn{4}{|c|}{ Pool } & \multicolumn{4}{|c|}{ Rapids } \\
\hline & & & LY & $\mathrm{PF}$ & $\mathrm{F}$ & PosF & LY & $\mathrm{PF}$ & $\mathrm{F}$ & PosF \\
\hline \multicolumn{11}{|l|}{ Atheriniformes } \\
\hline \multicolumn{11}{|l|}{ Atherinopsidae } \\
\hline Odontesthes aff. perugiae & 2.78 & 3 & 1 & 1 & & 1 & & & & \\
\hline \multicolumn{11}{|l|}{ Characiformes } \\
\hline \multicolumn{11}{|l|}{ Acestrorhynchidae } \\
\hline Acestrorhynchus pantaneiro & 0.93 & 1 & & & & & 1 & & & \\
\hline \multicolumn{11}{|l|}{ Anostomidae } \\
\hline Leporinus amae & 6.48 & 23 & 12 & 9 & 1 & & 1 & & & \\
\hline Leporinus obtusidens & 14.81 & 61 & & 52 & 5 & 2 & & 1 & 1 & \\
\hline Schizodon aff. nasutus & 3.7 & 6 & & 3 & & & & 3 & & \\
\hline \multicolumn{11}{|l|}{ Characidae } \\
\hline Astyanax jacuhiensis & 7.41 & 14 & & & & 10 & 1 & 2 & 1 & \\
\hline Astyanax fasciatus & 0.93 & 2 & & 2 & & & & & & \\
\hline Astyanax gr. scabripinnis & 5.56 & 6 & & 2 & & & 3 & 1 & & \\
\hline Astyanax spp. & 1.85 & 2 & & & & & 2 & & & \\
\hline Bryconamericus spp. & 0.93 & 1 & & & & & & 1 & & \\
\hline Bryconamericus iheringii & 9.26 & 62 & & 26 & & 35 & 1 & & & \\
\hline Bryconamericus stramineus & 8.33 & 30 & & 19 & 7 & 4 & & & & \\
\hline Galeocharax humeralis & 0.93 & 2 & & 2 & & & & & & \\
\hline Oligosarcus brevioris & 1.85 & 3 & & 3 & & & & & & \\
\hline Serrasalmus maculatus & 2.78 & 3 & & 3 & & & & & & \\
\hline \multicolumn{11}{|l|}{ Crenuchidae } \\
\hline Characidium spp. & 0.93 & 1 & & & & & & & & 1 \\
\hline \multicolumn{11}{|l|}{ Curimatidae } \\
\hline Steindachnerina spp. & 0.93 & 2 & & 2 & & & & & & \\
\hline \multicolumn{11}{|l|}{ Erythrinidae } \\
\hline Hoplias spp. & 3.7 & 24 & & & & 23 & 1 & & & \\
\hline \multicolumn{11}{|l|}{ Parodontidae } \\
\hline Apareiodon affinis & 2.78 & 6 & & & & & 6 & & & \\
\hline \multicolumn{11}{|l|}{ Perciformes } \\
\hline \multicolumn{11}{|l|}{ Sciaenidae } \\
\hline Pachyurus bonariensis & 0.93 & 1 & & 1 & & & & & & \\
\hline \multicolumn{11}{|l|}{ Siluriformes } \\
\hline \multicolumn{11}{|l|}{ Heptapteridae } \\
\hline Rhamdia quelen & 0.93 & 1 & & & & & & 1 & & \\
\hline \multicolumn{11}{|l|}{ Loricariidae } \\
\hline cf. Rhinelepis & 0.93 & 1 & 1 & & & & & & & \\
\hline Hypostomus spp. & & & & & & $1 *$ & & & & $1^{*}$ \\
\hline Loricariichthys spp. & 0.93 & 16 & & & & $16^{*}$ & & & & \\
\hline Pimelodidae & & & & & & & & & & \\
\hline Pimelodus maculatus & 0.93 & 1 & 1 & & & & & & & \\
\hline
\end{tabular}

found during the months of January, February, and March in the rapids environment $(F(5,96)=10.196, p<0.05$, Fig. 9a).

A larger number of larvae in the flexion stage were captured in the pool environment in December $(\mathrm{F}(5,96)=4.7805, \mathrm{p}<0.05$, Fig. 9b) and in the postflexion stage in December and February $(F(5,96)=2.6966, p<0.05)$, similar to the observations in the pool environment (Fig. 9c).

\section{Relationship between environmental factors and ichthyoplankton development}

The CCA showed a significant correlation between the environmental data and the distribution of the development stages $(\mathrm{P}<0.05$; Table 3$)$. In total, the first $\mathrm{CCA}$ axis explained
$44.9 \%$ of the data variation. The CCA axis 1 demonstrated the highest percentage explanation of the data $(36.3 \%)$. Along this axis, segregation between the larval stages can be observed, with the abundance of eggs and larvae in the larval yolk stage seeming to be more associated with the increase in water velocity, whereas the preflexion, flexion and postflexion stages seem to be linked to the increase in water transparency (Fig. 10, Table 3).

\section{Discussion}

Of the nearly 100 fish species described in the basin of the upper Uruguay River (Zaniboni-Filho et al., 2004), 18 

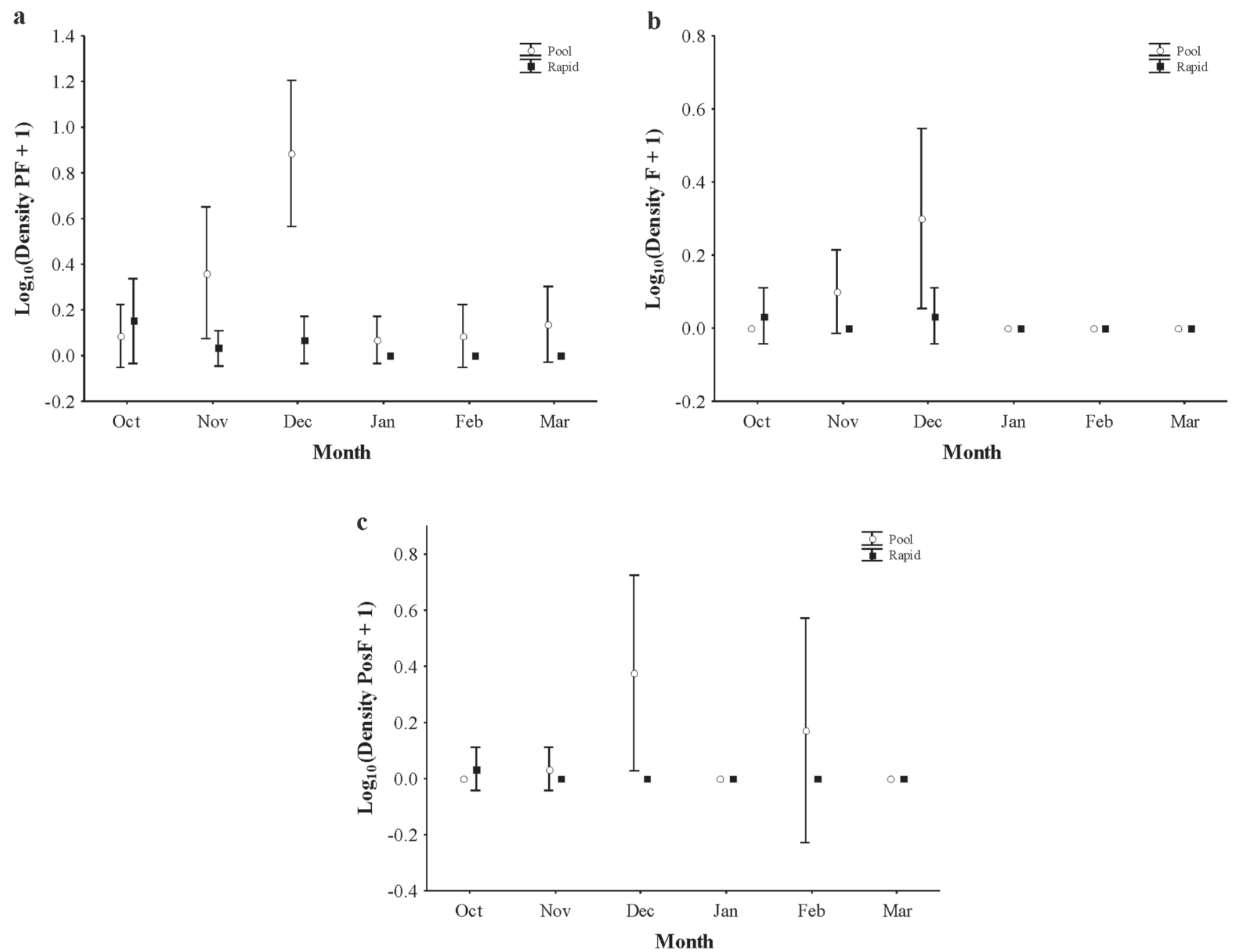

Fig. 9. Average density \pm standard error of the different larval stages captured in the rapids and pool environments of the Peixe River. Period from October 2011 to March 2012. Larval stages: Preflexion (a), Flexion (b) and Postflexion (c).

species were present among the larvae captured in the Peixe River, which indicates that these species have been using this environment as a spawning and breeding site during their initial stages of life. Of the two analyzed environments, the greatest species diversity was found in the pool environment, which presented 15 out of the 18 species found. In the rapids, $50 \%$ of the species were captured. Despite the difference in the number of captured species between the two environments, the primary fish orders found both in the pool and in the rapids were the Characiformes and Siluriformes. The dominance of these two orders has also been described by several authors for the neotropical freshwater region (Agostinho et al., 1997; Lowe-McConnell, 1999; Agostinho et al., 2003; Reynalte-Tataje et al., 2012b).

The larvae assemblage found in the Peixe River was primarily composed of sedentary species, which tend to exhibit opportunistic features, i.e., small and medium sized, few eggs, do not perform large migrations and have no parental care (Vazzoler, 1996). However, the important fact present in the study was the capture of Leporinus obtusidens larvae because this is the first noted presence of migratory fish in this region, which is under direct influence of the reservoir dam. Leporinus obtusidens larvae were found in both studied environments; although a larger abundance of these larvae was recorded in the pool environment. Larvae of this species in more advanced stages (flexion and postflexion) were only verified in the pool environment, indicating that more developed larvae tend to group in places with lentic characteristics. Previously, Reynalte-Tataje et al. (2012c) have reported the occurrence of eggs of migratory fish in the upper Uruguay River under the direct influence of dams but not in the region of the Peixe River. These recent findings indicate not only that migratory fish are finding adequate sites for their spawning but also that certain larvae from this group may be using environments found in the tributary rivers to develop. In the case of the upper Uruguay River, it is possible that after the construction of dams, and consequent river fragmentation, the fish species that previously performed long migrations in their reproductive period in the main river and in the connected tributaries are successfully maintaining 
Table 2. Average values of the abiotic variables in different environments from October 2011 to March 2012. Variation amplitude is shown in brackets.

\begin{tabular}{lcc}
\hline \multirow{2}{*}{ Abiotic variables } & \multicolumn{2}{c}{ Sampling sites } \\
\cline { 2 - 3 } & $25.3 \pm 2.6$ & $25.4 \pm 2.7$ \\
Temperature $\left({ }^{\circ} \mathrm{C}\right)$ & $(19.4-29.0)$ & $(19.5-29.0)$ \\
& & \\
\multirow{2}{*}{ Dissolved oxygen $(\mathrm{mg} / \mathrm{L})$} & $(5.46 \pm 1.34-9.53)$ & $(4.37 \pm 1.28$ \\
& & \\
$\mathrm{pH}$ & $8.15 \pm 0.84$ & $8.00 \pm 0.56$ \\
& $(7.25-10.06)$ & $(7.32-9.21)$ \\
Electrical conductivity $(\mu \mathrm{S} / \mathrm{cm})$ & $78.13 \pm 32.13$ & $77.61 \pm 33.11$ \\
& $(21.00-125.00)$ & $(24.00-127.00)$ \\
Transparency $(\mathrm{cm})$ & $99.2 \pm 48.7$ & $99.7 \pm 48.6$ \\
& $(35.0-160.0)$ & $(36.0-160.0)$ \\
Water speed $(\mathrm{m} / \mathrm{s})$ & $0.41 \pm 0.22$ & \\
\hline
\end{tabular}

reproductive activity through lateral displacements in the tributaries with lotic characteristics, which is the case of the Peixe River. These tributaries seem to offer adequate conditions for the reproduction of several fish species, playing a relevant part in the maintenance of fish assemblages in the region.

In addition, apart from L. obtusidens larvae of other species that perform short reproductive migrations, such as Leporinus amae, Rhamdia quelen, and Pimelodus maculatus were also found in the Peixe River. This result contributes to the hypothesis that different migratory species seem to have found adequate habitats for their reproduction and larval development in this tributary.

Through the analysis of the larval digestive tract in both studied environments, it was possible to observe a lower feeding activity of the larvae in the rapids. Because most of the larvae found in this environment had some vestige of yolk, it can be inferred that the low degree of stomach repletion of larvae in the rapids is because the larvae they are still feeding endogenously. During the first days after eclosion, larvae feed through the endogenous yolk sac and the gradual depletion of this reserve or full nutrition causes the larva to seek an exogenous food source (Kjorsvik et al., 2006). Consequently, it is possible to infer that the local growth of larval fish should be environments where biological and physicochemical conditions are appropriate for the growth of their larvae, with food availability both for their development and their feeding (Reynalte-Tataje et al., 2008b).

In the pool, the presence of larvae with partially full and full repletion degrees seems to indicate that the species have been using these habitats as feeding sites. The low flow in these environments apparently promotes adequate conditions for young individuals to feed. According to Houde (2002) and Werner (2002), the stream and the residence time of water are considered important factors in providing good conditions for the development of the younger forms.

For the larvae of species that migrate to reproduce, such
Table 3. Results of the canonical correlation analysis (CCA) performed with the abundance of eggs and larval stage and the environmental variables observed in different sampling sites of the Peixe River, upper Uruguay River, between October 2011 and March 2012. *Values with statistical significance $(\mathrm{P}<0.05)$.

\begin{tabular}{lcc}
\hline & Axis 1 & Axis 2 \\
\hline Eigenvalue & 0.381 & 0.09 \\
Cumulative percentage of variance explained by & 36.3 & 8.6 \\
$\quad$ stages-environment & $0.789^{*}$ & 0.584 \\
Stages-Environment Correlation & & \\
Correlation between environmental variables and & & \\
$\quad$ canonical axes & $-0.824^{*}$ & 0.215 \\
Water velocity & $0.503^{*}$ & 0.175 \\
\hline Transparency & & \\
\hline Total inertia: 1.0481 & & \\
\hline
\end{tabular}

as L. obtusidens and L. amae, feeding activity was only observed in the pool environment. This information is of extreme relevance because more lentic stretches in the main channel of the river, such as the pools, have been used as nurseries for several fish species - including migratory ones and may be contributing to the maintenance of their stocks. However, there is a need for more studies in the region, with the objective of verifying the effective recruitment of migratory species to these environments.

Regarding the spatio-temporal variation of ichthyoplankton abundance we observed that Peixe River presented a different proportion of captured eggs (74\%) and larvae (26\%) from that observed by Silva et al. (2012) in the Ligeiro River (a tributary of the upper Uruguay River), which registered a vast domain of eggs $(95 \%)$. This difference may be related to the type of material used for the capture of the ichthyoplankton because the light trap, as a passive collection process, is more efficient in the capture of larvae and juveniles rather than eggs (Peterson \& Vanderkooy, 1995; Vilizzi et al., 2008).

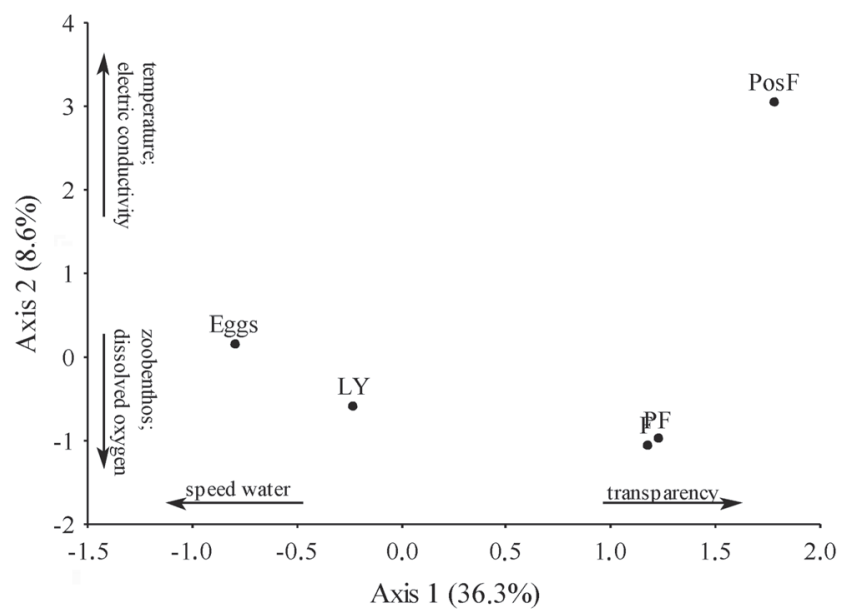

Fig. 10. Canonical correlation analysis relating the abundance of the different larval stages from October 2011 to March 2012. Eggs: eggs; LY: larval yolk; PF: preflexion; F: flexion; PosF: postflexion. 
Similar to the observations of studies performed in the tributaries of the upper Uruguay River (Correa et al., 2010) and the Paraná River (Reynalte-Tataje et al., 2011), the greatest abundance of larvae in this paper occurred in December. Through analysis of the larvae capture data, it was possible to observe that from the preflexion stage, the larvae presented a difference in their spatial-temporal distribution, with the highest values being found in December in the pool environment for the three stages (preflexion, flexion, and postflexion). This result indicates that the larvae in more advanced stages tend to prefer calmer environments that, according to Houde (2002) and Werner (2002), offer better conditions for their development. Several authors (Humphries et al., 1999; King et al., 2003; King, 2004) maintain that in regions of rivers that do not present a floodplain, the main channel provides lateral habitats along the banks that are adequate for larvae development.

The relationship between environmental factors and ichthyoplankton has been assessed through the analysis of the results presented by CCA, with which it was possible to observe that eggs and yolked larvae showed a positive correlation with water velocity. This result indicates the drift of eggs and larvae in the early stages because the transportation of eggs increases their oxygenation and prevents them from being deposited on the bottom. Larvae with yolk also benefit from passive transport because at this stage, the larva shows low swimming performance. The absence of a positive relationship between water velocity and the more advanced stages seems to indicate a preference of these stages for quieter locations. The highest correlation between the larvae in more advanced stages and the transparency of water may be related to the efficiency of the light traps in environments with lower turbidity (Floyd et al., 1984; Doherty, 1987).

The analysis of the ichthyoplankton from the Peixe River confirmed the hypothesis that the more developed larvae have been using the pool as a natural nursery for their growth. Therefore, in contrast to what was presented by other authors (Cushing, 1990; Reynalte-Tataje et al., 2011), the food offered, such as macrozooplankton and benthonic organisms, does not appear to be the main reason that larvae in more advanced development stages are occupying the pool environment; no differences were found between the abundance of these organisms in both analyzed environments. Apparently, with the development of sensorial and swimming capacities, the larvae prefer the pool environments. Thus, a possible explanation for the larger quantity of ontogenetically more developed larvae found in the pool would be that in this environment, the larvae are better prepared, waste less energy and easily capture their prey. The segregation of the developmental stages in both environments confirms the hypothesis initially presented, which stated that the more developed stages preferably use pool habitats as their growth place (Fig. 11).

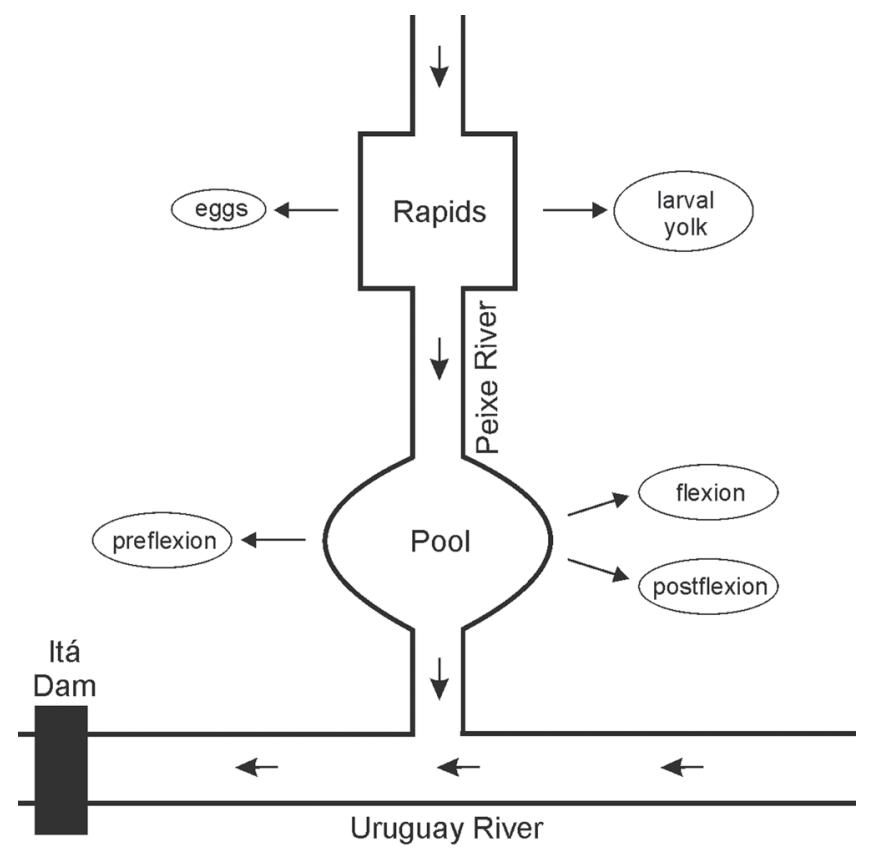

Fig. 11. Conceptual model of the distribution patterns of eggs and larvae in the early stages of two environments in the Peixe River (upper Uruguay River), from October 2011 to March 2012.

The information presented in this paper emphasizes the importance of the mosaic of river environments in the life cycle of fish and shows the necessity of maintaining lotic stretches in the management of watersheds. In the studied stretch of the upper Uruguay River, the rapids and pool are essential for the life cycle of several fish species, including the migratory L. obtusidens. Therefore, future investigations are necessary to demonstrate these spawning and growth areas can efficiently guarantee the recruitment of migratory fish species in the region.

\section{Acknowledgments}

The authors would like to thank the coworkers from LAPAD (CCA/UFSC) for their help in field sampling and sample sorting. This work is part of the project "Monitoring and management of the ichthyofauna at Itá hydroelectric power station" (Monitoramento e manejo da Ictiofauna da UHE Itá), supported by TRACTEBEL ENERGIA, CAPES, and CNPq.

\section{Literature Cited}

Agostinho, A. A., L. C. Gomes, H. I. Suzuki \& H. F. Junior. 2003. Migratory fishes of the upper Paraná River Basin, Brazil. Pp. 19-98. In: Carolsfeld, J., B. Harvey, A. Baer \& C. Ross (Eds.). Migratory fishes of the South America: biology, social importance and conservation status. Victoria, World Fisheries Trust. 
Agostinho, A. A., H. F. Júlio Jr., L. C. Gomes, L. M. Bini \& S. Agostinho. 1997. Composição, abundância e distribuição espaço-temporal da ictiofauna. Pp. 179-208. In: Vazzoler, A. E. A. M., A. A. Agostinho \& N. S. Hahn (Eds.). A planície de inundação do alto rio Paraná: aspectos físicos, biológicos e socioeconômicos. Maringá, Editora da UEM.

Ahlstrom, E. H. \& H. G. Moser. 1976. Eggs and larvae offishes and their role in systematic investigations and in fisheries. Revue des Travaux de l'Institut des Pêches Maritimes, 40: 379-398.

Baumgartner, G., K. Nakatani, L. C. Gomes, A. Bialetzki, P. V. Sanches \& M. C. Makrakis. 2004. Identification of spawning sites an natural nurseries in the upper Paraná river. Environmental Biology of Fishes, 71: 115-125.

Castro, R. J., K. Nakatani, A. Bialetzki, P. V. Sanches \& G. Baumgartner. 2002. Temporal distribution and composition of the ichthyoplankton from Leopoldo's Inlet on the upper Paraná River floodplain (Brazil). Journal of Zoology, 256: 437-443.

Copp, G. H., J. M. Oliver, M. Penaz \& M. R. Roux. 1991. Juvenile fishes as functional describes of fluvial ecosystem dynamics: application on the river Rhone, France. Regulated Rivers: Research and Management, 6: 135-199.

Correa, R. N., S. Hermes-Silva, D. A. Reynalte-Tataje \& E. ZaniboniFilho. 2010. Distribution and abundance of fish eggs and larvae in three tributaries of the upper Uruguay River (Brazil). Environmental Biology of Fishes, 91: 51-61.

Cushing, D. H. 1990. Plankton production and year-class strength in fish populations: an update of the match/mismatch hypothesis. Advanced Marine Biology, 26: 249-292.

Doherty, P. J. 1987. Light-traps: selective but useful devices for quantifying the distributions and abundances of larval fishes. Bulletin of Marine Science, 41: 423-431.

Floyd, K. B., R. D. Hoyt \& S. Timbrook. 1984. Chronology of appearance and habitat partitioning by stream larval fishes. Transactions of the American Fisheries Society, 113: 217-223.

Galat, D. L. \& I. Zweimüller. 2001. Conserving large-river fishes: is the highway analogy and appropriate paradigm? Journal of the North American Benthological Society, 20: 266-279.

Hermes-Silva, S., D. A. Reynalte-Tataje \& E. Zaniboni-Filho. 2009. Spatial and temporal distribution of ichthyoplankton in the upper Uruguay River, Brazil. Brazilian Archives of Biology and Technology, 52: 933-944.

Houde, E. D. 2002. Mortality. Pp. 64-87. In: Fuiman, L. A. \& R. G. Werner (Eds.). Fishery science the unique contributions of early life stages. Oxford, Blackwell Sciences.

Humphries, P., L. Serafini \& A. J. King. 2002. River regulation and fish larvae: variation through space and time. Freshwater Biology, 47: 1307-1331.

Humphries, P., A. J. King \& J. D. Koehn. 1999. Fish, flows and flood plains: links between freshwater fishes and their environment in the Murray-Darling River system, Australia. Environmental Biology of Fishes, 56: 129-151.

Junk, W. J., P. B. Bayley \& R. E. Sparks. 1989. The flood pulse concept in river-floodplain systems. Canadian Special Publication of Fisheries and Aquatic Sciences, 106: 110-127.

King, A. J. 2004. Ontogenetic patterns of habitat use by fishes within the main channel of an Australian floodplain river. Journal of Fish Biology, 65: 1582-1603.

King, A. J., P. Humphries \& P. S. Lake. 2003. Fish recruitment on flood plains: The roles of patterns of flooding and life history strategies. Canadian Journal of Fisheries and Aquatic Sciences, 60: 773-786.
Kjorsvik, E., T. Meeren, H. Kryvi, J. Arnfinnsom \& P. G. Kvenseth. 2006. Early development of the digestive tract of cod larvae, Gadus morhua L., during startfeeding and starvation. Journal of Fish Biology, 38: 1-15.

Lowe-McConnell, R. H. 1999. Estudos ecológicos de comunidades de peixes tropicais. São Paulo, Editora da Universidade de São Paulo.

Marçal-Simabuku, M. A. \& A. C. Peret. 2002. Alimentação de peixes (Osteichthyes, Characiformes) em duas lagoas de uma planície de inundação brasileira da bacia do rio Paraná. Interciencia, 27: 299-306.

Nakatani, K., A. A. Agostinho, G. Baumgartner, A. Bialetzki, P. V. Sanches, M. C. Makrakis \& C. S. Pavanelli. 2001. Ovos e larvas de peixes de água doce: desenvolvimento e manual de identificação. Maringá, Editora da UEM.

Penczak, T. 1994. Fish recruitment in the Warta River (1985-1992): impoundment study. Polskie Archiwum Hydrobiologii, 41: 293300.

Peters, R. K. 1986. The role of prediction in limnology. Limnology and Oceanography, 31: 1143-1159.

Peterson, M. S. \& S. J. Vanderkooy. 1995. Phenology and spatial and temporal distribution of larval fishes in a partially channelized warm water stream. Ecology of Freshwater Fish, 4: 93-105.

Reynalte-Tataje, D. A., V. Garcia, M. C. Nunes, C. A. Lopes \& E. Zaniboni-Filho. 2012a. Armadilhas luminosas e o ictioplâncton. Pp. 107-126. In: Zaniboni-Filho, E. \& A. P. O. Nuñer (Orgs.). Reservatório de Machadinho: peixes, pesca e tecnologias de criação. Florianópolis, Editora UFSC.

Reynalte-Tataje, D. A., E. Zaniboni-Filho, A. Bialetzki \& A. A. Agostinho. 2012b. Temporal variability of fish larvae assemblages: influence of natural and anthropogenic disturbances. Neotropical Ichthyology, 10: 837-846.

Reynalte-Tataje, D. A., A. P. O. Nuñer, M. C. Nunes, V. Garcia, C. A. Lopes \& E. Zaniboni-Filho. 2012c. Spawning of migratory fish species between two reservoirs of the upper Uruguay River, Brazil. Neotropical Ichthyology, 10: 829-835.

Reynalte-Tataje, D. A., K. Nakatani, R. Fernandes, A. A. Agostinho \& A. Bialetzki. 2011. Temporal distribution of ichthyoplankton in the Ivinhema River (Mato Grosso do Sul State/ Brazil): influence of environmental variables. Neotropical Ichthyology, 9: 427-436.

Reynalte-Tataje, D. A. \& E. Zaniboni-Filho. 2008. Pp. 229-256. Biologia e identificação de ovos e larvas de peixes do alto rio Uruguai. In: Zaniboni-Filho, E. \& A. P. O. Nuñer (Orgs.). Reservatório de Itá. Estudos ambientais, desenvolvimento de tecnologia e conservação da ictiofauna. Florianópolis, Editora UFSC.

Reynalte-Tataje, D. A., S. Hermes-Silva, M. M. C. Silva, F. M. Abbud, R. N. Correa \& E. Zaniboni-Filho. 2008a. Distribuição de ovos e larvas de peixes na área de influência do reservatório de Itá (Alto rio Uruguai). Pp. 127-158. In: Zaniboni-Filho, E. \& A. P. O. Nuñer (Orgs.). Reservatório de Itá: Estudos ambientais, desenvolvimento de tecnologias de cultivo e conservação de ictiofauna. Florianópolis, Editora UFSC.

Reynalte-Tataje, D. A., S. Hermes-Silva, P. A. Silva, A. Bialetzki \& E. Zaniboni-Filho. 2008b. Locais de crescimento de larvas de peixes na região do Alto Rio Uruguai. Pp. 159-194. In: ZaniboniFilho, E. \& A. P. O. Nuñer (Orgs.). Reservatório de Itá: Estudos ambientais, desenvolvimento de tecnologias de cultivo e conservação de ictiofauna. Florianópolis, Editora UFSC. 
Silva, P. A., D. A. Reynalte-Tataje \& E. Zaniboni-Filho. 2012. Identification of fish nursery areas in a free tributary of an impoundment region, upper Uruguay River, Brazil. Neotropical Ichthyology, 10: 425-438.

Ter Braak, C. J. F. 1995. Ordination. Pp. 91-173. In: Jongman, R. H. G., C. J. F. Ter Braak \& O. F. R. Van Tongeren (Eds.). Data analysis in community and landscape ecology. Cambridge, Cambridge University Press.

Vazzoler, A. E. A. M. 1996. Biologia da reprodução de peixes teleósteos: teoria e prática. Maringá, Editora da UEM.

Vilizzi, L., S. N. Meredith, C. P. Sharpe \& R. Rehwinkel. 2008. Evaluating light trap efficiency by application of mesh to prevent inter- and intra-specific in situ predation on fish larvae and juveniles. Fisheries Research, 93: 146-153.

Welcomme, R. L. 1985. River Fisheries. FAO Fisheries Technical Paper, 262: 330.

Welcomme, R. L. 1979. Fisheries ecology of floodplain rivers. London, Logman.

Werner, R. G. 2002. Habitat requirements. Pp. 161-182. In: Fuiman, L. A. \& R. G. Werner (Eds.). Fisheries Science: the unique contributions of early life stages. Oxford, Blackwell Science.

Zaniboni-Filho, E., S. Meurer, O. A. Shibatta \& A. P. O. Nuñer. 2004. Catálogo ilustrado de peixes do Alto Rio Uruguai. Florianópolis, Editora UFSC/Tractebel Energia.

Zaniboni-Filho, E. \& U. E. Schulz. 2003. Migratory fishes of the Uruguay River. Pp. 135-168. In: Carolsfeld, J., B. Harvey, A. Baer \& E. C. Ross (Eds.). Migratory fishes of the South America: biology, social importance and conservation status. Victoria, World Fisheries Trust.

Submitted July 19, 2013

Accepted February 4, 2014 by Paulo Pompeu

Published September 30, 2014 